\title{
Stabilisation of beta and gamma oscillation frequency in the mammalian olfactory bulb
}

\author{
Nicolas Fourcaud-Trocmé ${ }^{1,2^{*}}$, Emmanuelle Courtiol ${ }^{1,2}$, Nathalie Buonviso ${ }^{1,2}$, Thomas Voegtlin ${ }^{3}$ \\ From Twentieth Annual Computational Neuroscience Meeting: CNS*2011 \\ Stockholm, Sweden. 23-28 July 2011
}

The dynamics of the mammalian olfactory bulb (OB) is characterized by local field potential (LFP) oscillations either slow, in the theta range $(2-10 \mathrm{~Hz}$, tightly linked to the respiratory rhythm), or fast, in the beta $(15-30 \mathrm{~Hz})$ or gamma $(40-90 \mathrm{~Hz})$ range. These fast oscillations are known to be modulated by odorant features [1] and animal experience or state [2][3], but both their mechanisms and implication in coding are still not well understood. In this study, we used a double canulation protocol to impose artificial breathing rhythms to anesthetized rats while recording the LFP in the OB. We observed that despite the changes in the input air flow parameters (frequency or flow rate), the main characteristics of fast oscillations (duration, frequency or amplitude) were merely constant. We thus made the hypothesis that fast beta and gamma oscillations dynamics are entirely determined by the OB network properties and that external stimulation was only able put the network in a state which permits the generation of one or the other oscillations (they are never present simultaneously).

To test this hypothesis, we studied a simplified OB model based on previous modeling studies. In particular it includes resonant mitral cells [4] and graded synaptic inhibition [5]. Detailed analysis and numerical simulations of the model showed that two oscillatory dynamical regime can be sustained.

First, a low noise regime where at each cycle, a subset of mitral cells are tightly synchronized and yield a saturation of the graded inhibition, during which mitral cell discharge is prevented. Because of this saturation, the network frequency is governed by the dynamics of the graded inhibition decay. Interestingly, this dynamics

\footnotetext{
* Correspondence: nfourcau@olfac.univ-lyon1.fr

'INSERM U1028; CNRS UMR5292; Lyon Neuroscience Research Center,

Olfaction: from coding to memory Team, Lyon, F-69000, France

Full list of author information is available at the end of the article
}

is not very sensitive to the number of mitral cells that lead to the saturation. Consequently, there is a wide range of mitral cell firing rate during which the network frequency is stable. Using standard parameters in our model, we found an oscillation frequency stable between 25 and $30 \mathrm{~Hz}$ while the average mitral cell firing rate increased from $5 \mathrm{~Hz}$ to $25 \mathrm{~Hz}$.

Second, a high noise regime can be observed where the mitral cell discharge is much less regular. In this case, the network oscillations are of lower amplitude compared to the low noise regime and thus the graded inhibition is never saturated by fluctuations around its mean. The network can then be well described by a mean field approach (as described in [6]) and is close to a previous model of in vitro gamma oscillations [4]. With our model parameters, oscillations in this regime have higher frequency, typically in the gamma range $(50 \mathrm{~Hz}-90 \mathrm{~Hz})$ but their frequency is highly sensitive to the level of input excitation to the mitral cells. This discrepancy with our experimental result could be relieved by the in vitro experimental observation that mitral cell stimulus excitatory input is all or none [7]. Indeed this could provide a stable external input to the network and thus also stabilize the gamma frequency.

Finally, we have shown that our model can account for the two stable oscillatory regimes observed in the $\mathrm{OB}$ in vivo. However our model does not take into account the spatial activation of the $\mathrm{OB}$ and the study of how spatially segregated oscillatory generators interact and potentially synchronize is an ongoing work.

\section{Author details \\ 'INSERM U1028; CNRS UMR5292; Lyon Neuroscience Research Center, Olfaction: from coding to memory Team, Lyon, F-69000, France. ²University Lyon 1, Lyon, F-69000, France. ${ }^{3}$ Equipe Cortex, INRIA Lorraine; Vandoeurre- les-Nancy, France.}

Published: 18 July 2011 


\section{References}

1. Cenier T, Amat C, Litaudon P, Garcia S, Lafaye de Micheaux P, Liquet B, Roux S, Buonviso N: Odor vapor pressure and quality modulate local field potential oscillatory patterns in the olfactory bulb. Eur J Neurosci 2008, 27:1432-1440.

2. Freeman WJ, Schneider W: Changes in spatial patterns of rabbit olfactory EEG. Psychophysiology 1982, 19:44-56.

3. Ravel N, Chabaud P, Martin C, Gaveau V, Hugues E, Tallon-Baudry C, Bertrand $\mathrm{O}$, Gervais R: Olfactory learning modifies the expression of odour-induced oscillatory responses in the gamma $(60-90 \mathrm{~Hz})$ and beta (15-40 Hz) bands in the rat olfactory bulb. Eur J Neurosci 2003, 17:350-358.

4. Bathellier B, Lagier S, Faure P, Lledo P: Circuit properties generating gamma oscillations in a network model of the olfactory bulb. $J$ Neurophysiol 2006, 95:2678-2691.

5. Brea J, Kay K, Kopell N: Biophysical model for gamma rhythms in the olfactory bulb via subthreshold oscillations. Proc Natl Acad Sci U S A 2009, 106(51):21954-21959.

6. Geisler C, Brunel N, Wang XJ: Contributions of intrinsic membrane dynamics to fast network oscillations with irregular neuronal discharges. J Neurophysiol 2005, 94:4344-4361.

7. Gire DH, Schoppa NE: Control of On/Off Glomerular Signaling by a Local GABAergic Microcircuit in the Olfactory Bulb. J Neurosci 2009, 29(43):13454-13464

doi:10.1186/1471-2202-12-S1-P362

Cite this article as: Fourcaud-Trocmé et al:: Stabilisation of beta and gamma oscillation frequency in the mammalian olfactory bulb. BMC Neuroscience 2011 12(Suppl 1):P362.

\section{Submit your next manuscript to BioMed Central} and take full advantage of:

- Convenient online submission

- Thorough peer review

- No space constraints or color figure charges

- Immediate publication on acceptance

- Inclusion in PubMed, CAS, Scopus and Google Scholar

- Research which is freely available for redistribution

Submit your manuscript at www.biomedcentral.com/submit 